\title{
Do Parenting Plans Work? The Effect of Parenting Plans on Procedural, Family and Child Outcomes
}

\author{
Simon de Bruijn, ${ }^{*}$ Anne-Rigt Poortman,* and Tanja van der Lippe* \\ ${ }^{*}$ Utrecht University, The Nethelands
}

\section{ABSTRACT}

The Dutch legislature obligated divorcing parents to draw up a parenting plan when they divorce because it believed such a plan to be beneficial for reducing procedural and family-related problems, and ultimately increasing child well-being. In this study, the authors evaluate the effectiveness of the parenting plan for both procedural, family and child outcomes simultaneously, using a natural experiment. They use recent survey data from the Netherlands $(n=1,470)$ and make a distinction between parents who divorced prior to the 2009 divorce law and those who divorced after its enactment. The implementation of the mandatory parenting plan encouraged more parents to document their agreements in writing. These written arrangements are found to be more comprehensive and are updated more often after the 2009 divorce law. With respect to the other procedural outcomes no difference with the situation before the change of the law is found. Findings regarding parental conflict are mixed, post-divorce tension increased after the 2009 divorce law, whereas extreme occurrences of parental conflict decreased. No differences are found in the level of parental contact. Additionally, the parenting plan is not found to affect child well-being, both directly and mediated through procedural and family outcomes. Most of these findings may be attributed to the fact that prior to the 2009 law reform many divorcing parents already made written arrangements regarding their children. Suggestions for further research regarding the parenting plan and possible other implications are discussed.

\section{INTRODUCTION}

Divorce is a stressful life event that may negatively impact children (Lamb et al, 1997). In an attempt to overcome these negative effects, the Dutch government, like the authorities in many other countries, introduced new divorce legislation in 2009. The divorce law (the Promotion of Continued Parenting and Proper Divorce Act) states that children have the right to equal care by both parents after divorce. The law also made it mandatory for both separating and divorcing parents of minor children to draw up a parenting plan (Staatsblad, 2008), which is a binding agreement that entails how parents will exercise their parental responsibilities in the postdivorce period. Additionally, the Dutch government also obliges parents to explain in what way their child participated in drafting the parenting plan (Smits, 2015). 
Ironing out problems in divorce proceedings (e.g. lengthy litigation) and mitigating the harmful effects divorce can have on family life (e.g. parental conflict) are central to the 2009 divorce law. Ultimately, reducing procedural and family-related problems are assumed to enhance child well-being. The assumption that a parenting plan will be in the child's interest is controversial in public and scientific debate, with some people contending that the mandatory nature of the plan will lead to more acrimonious divorces (Coenraad and Antokolskaia, 2010) and thus lower levels of child well-being. Their mandatory nature may also make parenting plans more of a formality than a well-considered document (Loeb, 2009), which could undermine the assumed positive effects. If so, parenting plans may have no or even negative effects.

Only a few studies have examined the effectiveness of the Dutch parenting plan empirically, and most of these focus on procedural outcomes drawn from court documents. These studies reveal that the introduction of the mandatory parenting plan has led to more child-related agreements being made by divorcing parents than before 2009 (Tomassen-van der Lans, 2015). Whether the child actually participated in drafting the parenting plan is generally not explicitly examined by the court (Smits, 2015). Previous research is inconclusive about the effect of the new parenting plan on other aspects of divorce proceedings; Ter Voert and Geurts (2013) demonstrated that since the plan was introduced, legal conflicts have decreased or remained level, with the exception of court proceedings regarding parental authority (which have increased since 2012). Also, Tomassen-van der Lans (2015) found that, except for an increase in court decisions regarding the division of child care, the number of decisions remained the same after the parenting plan was introduced (Tomassen-van der Lans, 2015). With respect to litigation, there is no significant difference between the situation before and after introduction of the mandatory parenting plan (Tomassen-van der Lans, 2015). Regarding family outcomes, Spruijt and Kormos (2014) concluded that conflict has increased since the introduction of the parenting plan. Such higher levels of conflict have also found to influence child well-being negatively (Spruijt and Kormos, 2014). These results, however, are based on a relatively small sample and significant at the 10 percent level. Thus, previous research is mixed in its findings with respect to the effects of the parenting plan.

This study evaluates the effectiveness of the parenting plan for both procedural, family, and child outcomes simultaneously, using a natural experiment. The procedural outcomes under study are outcomes that may be affected due to the change in divorce proceedings, such as satisfaction and compliance with the agreements, but also whether the agreements were more comprehensive and whether a court ruling on (some points of) the agreement was necessary. The family outcomes under study concern the amount of contact between the parents and the level of parental conflict. Additionally, we also examine the direct effectiveness of the parenting plan on child well-being and whether a potential effect is mediated through the procedural and/or family outcomes. Using data from the New Families in the Netherlands survey (Poortman, Van der Lippe and Boele-Woelki, 2014), we compare parents who divorced prior to the 2009 divorce law with those who divorced after its enactment. Because the treatment assignment can be attributed to a policy change, our study qualifies as a natural experiment (Meyer, 1995). 
We contribute to the literature by examining procedural outcomes, family outcomes, and child outcomes related to the parenting plan simultaneously. Our examination of family outcomes is especially new in the literature on parenting plans, and our use of large-scale survey data also allows us to study contact between parents and parental conflict. Because we use recent, unique, large-scale survey data instead of court documents, we are able to examine outcomes that are not documented in legal proceedings. We investigate the subjective feelings of those involved in the divorce rather than what is agreed on in writing or documented under litigation. Also, using survey data allows us to include the somewhat milder cases omitted in court documents, since parents who face divorce-related problems but do not litigate will not appear in such documents. This also makes it possible to investigate a wide range of procedural outcomes, some of which have not been examined in previous studies (such as satisfaction and compliance with the agreements). We also contribute to the literature by examining whether parenting plans enhance child well-being and whether some effects related to child well-being are mediated through procedural and/or family outcomes.

\section{THE DUTCH PARENTING PLAN}

The introduction of the Promotion of Continued Parenting and Proper Divorce Act in 2009 made some explicit changes to Dutch family policies. One of the most critical changes, and also the focus of this study, is the obligation on divorcing parents of minor children to draw up a parenting plan (Schonewille, 2009). Parents are required to put their decisions regarding the post-divorce situation in writing in the plan. Parents are further obligated to describe how their child participated in making the arrangements (Smits, 2015). Under current Dutch legislation, the following points must at least be addressed in the parenting plan; the division of care and childrearing tasks, child support and other childrearing expenses and the way the parents intend to communicate and inform each other about important matters concerning their child (Staatsblad, 2008). Legal criteria are however uncertain, because the precise content of parenting plans is not enumerated by the legislator. Besides the mandatory items, parents are also encouraged to cover additional points in their parenting plan (Rijksoverheid, 2013). The Dutch government further advises parents to update the parenting plan when needed, because agreements made today may be outdated a few months later (Rijksoverheid, 2013). However, covering additional points in the parenting plan as well as updating the parenting plan is merely a suggestion, rather than a requirement. As a result, parenting plans may be different on several aspects such as content and comprehensiveness.

\section{Policy Background}

With the introduction of the Promotion of Continued Parenting and Proper Divorce Act in 2009 and thus the mandatory parenting plan and its corresponding norms and obligations, both parents have been required to make more tailor-made arrangements in their child's best interest (Schonewille, 2009). Before the introduction of the parenting plan, divorcing parents were free to decide whether and when they wanted to make binding agreements regarding their children and whether or not to 
put them in writing (Antokolskaia, 2010). Even though most parents already made agreements regarding their children, and even though the agreements set out in writing were documented in a divorce agreement, the procedure was voluntary and had not yet been formalized (Bunthof, 2006). Additionally, in practice more than half of divorcing parents already drew up written arrangements regarding their children before the introduction of the mandatory parenting plan (Ter Voert and Geurts, 2013).

Besides the mandatory parenting plan, the 2009 divorce law introduced further changes that must be borne in mind because they could influence our findings to some extent. First, since 1998 Dutch parents had already automatically retained shared parental authority after divorce, but the legislation introduced in 2009 made it more difficult for one of the parents to petition the court to award them sole parental authority (Schonewille, 2009). This change was in line with the standard of continued shared parenting after divorce as upheld by Dutch lawmakers (Schonewille, 2009), but it may have also resulted in a rise in legal proceedings regarding parental authority compared with the years before the 2009 divorce law. Second, the new law underscored the right to equal care by both parents. This can be attributed to, or perhaps is a result of, the increase in residential co-parenting in recent years (Poortman and Van Gaalen, 2017). Previous research has shown that shared residential co-parenting is associated with higher levels of child well-being (Westphal, 2015), a finding that we should take into account. To overcome the spurious effects of increases in residential co-parenting, we control for the child's current residential arrangement.

In this study, we describe how the parenting plan was expected to affect procedural outcomes and family outcomes by examining differences between the arrangements made by divorcing parents before and after the change in legislation. We follow the reasoning of Dutch lawmakers and how they assumed the mechanisms would work. These assumptions are illustrated in Figure 1.

\section{A. Procedural Outcomes}

The mandatory parenting plan was expected to reduce procedural problems between parents during divorce proceedings. As suggested by Schonewille (2009), a 'good' parenting plan goes beyond the legal minimum; it forces parents to carefully consider the facets of post-divorce parenting; it is in line with the needs of the child; and it allows parents to adapt and amend the plan as the child's needs change. Because divorcing parents are obliged to draw up a parenting plan, and are thus forced to think about the post-divorce period in greater detail than parents who divorced before the 2009 law, it encourages them to draw up more comprehensive agreements regarding their children. Also, because parents are now forced to make arrangements before they can finalize their divorce, they must consider them at an earlier stage of their divorce proceedings. As a result, parents discuss their arrangements with each other before addressing the court and are therefore less likely to ask for a court-issued ruling regarding their arrangements (acrimonious divorces excepted). Moreover, when parents reach agreement themselves, they are also less likely to have conflicts about their divorce proceedings (Schepard, 2001). 


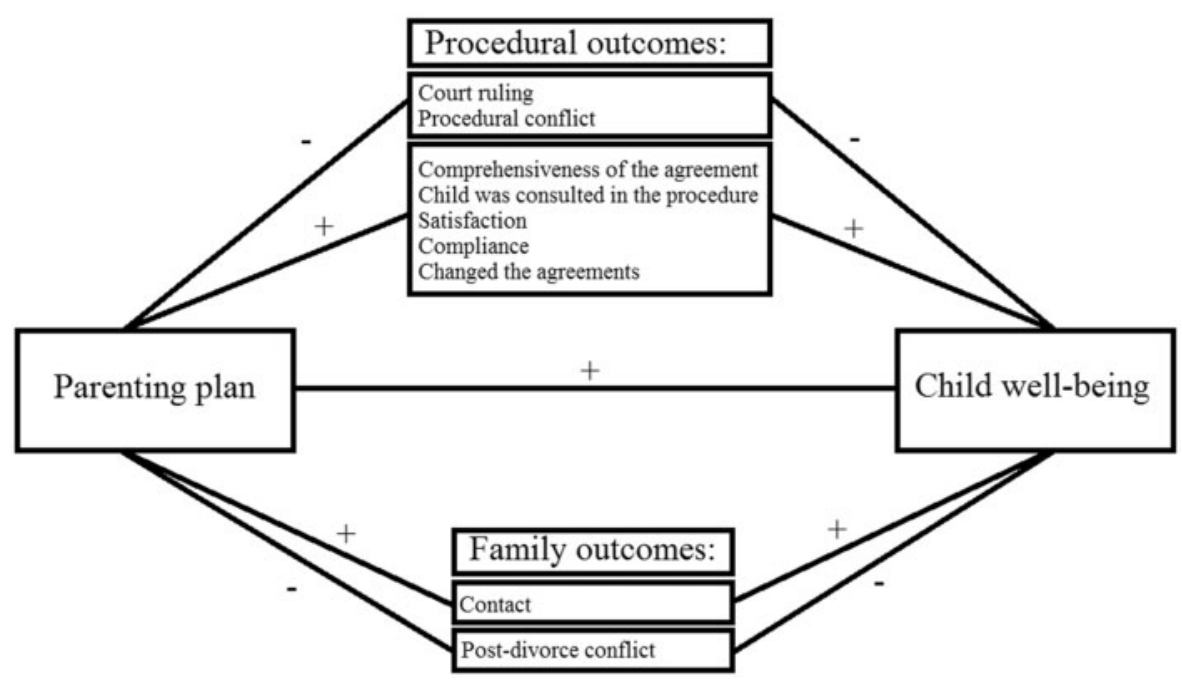

Figure 1. Diagram showing the effects of the parenting plan as assumed by Dutch lawmakers.

The parenting plan not only encourages parents to give careful thought to their child in the post-divorce period, but also requires them to demonstrate whether their child participated in making the agreements (Ministerie van Veiligheid en Justitie, 2012). The lawmakers' intention was to involve children more in decisions that affect them (Ministerie van Jeugd en Gezin, 2008), again highlighting the importance that the Dutch government attaches to the child's best interest. The fact that parents are now advised to think carefully about the post-divorce situation and to consult their children regarding these arrangements may lead to more well-considered arrangements but also to a smoother negotiation process. If so, parents are more likely to be satisfied and to comply with the arrangements. Also, if parents want arrangements that suit their situation, they have to amend the agreement accordingly. Because children are constantly developing and environments change all the time, Dutch lawmakers suggest that parents update their agreements throughout the post-divorce situation (Rijksoverheid, 2013). In sum, the parenting plan leads us to assume that parents make more comprehensive agreements, use less court-issued rulings, encounter fewer procedural conflicts, include their child more in the decision-making process, are more satisfied with their agreements, comply more with the agreements made, and are more likely to update/change their agreements after divorce (see Figure 1).

\section{B. Family Outcomes}

We expect that the introduction of the parenting plan has affected not only procedural outcomes but also family outcomes. In their parenting plan, parents must state explicitly how they will inform and consult each other regarding their children after divorce. This obligation may give parents the opportunity to regulate the manner and frequency of their contact, and this could have a positive effect on the amount of mutual contact compared to parents who divorced prior to the 2009 law. The 2009 law also stipulates that when parents share parental authority, each parent has a 
responsibility to nurture the ties between the child and the other parent (Artikel 247 lid 3 Boek $1 \mathrm{BW}$ ). This too might increase the level of parental contact.

Besides giving parents an opportunity to have more contact with each other, a parenting plan offers them guidance after their divorce and may even prevent parental conflict later (Rijksoverheid, 2009). Parents who have a parenting plan will not need to discuss every decision that pertains to their child because they have a legal document to fall back on. As a result, there is less risk of conflict between them. To summarize, parenting plans are assumed to increase parental contact and decrease parental conflict (see Figure 1).

\section{Child Well-being}

The main goal of the parenting plan is to mitigate the adverse consequences that parental divorce may have on child well-being. As Figure 1 shows, we assume that the parenting plan affects child well-being directly and indirectly. The parenting plan gives parents a document that entails how they will handle child care and all other child-related issues after divorce. It serves as a guideline for what they both agree is in the best interest of their child. Having and using this guideline offers the child structure and consistency and may mitigate the adverse consequences of divorce and thus enhance child well-being. Moreover, an important new element related to the introduction of the parenting plan is that parents are more aware of the factors involved in divorce and what is in their child's best interest (Ministerie van Jeugd en Gezin, 2008). The aim of the parenting plan is to improve parents' awareness of the problems that their divorce may cause their child and to put the child's interests front and center throughout the entire divorce process (Ministerie van Jeugd en Gezin, 2008). Again, this may well enhance child well-being.

The effect of the parenting plan may also be more indirect. Earlier, we discussed how the parenting plan affects procedural and family outcomes, but these outcomes may also affect child well-being. Figure 1 shows the assumed effects according to the Dutch government's reasoning. The lines at the top of the figure suggest that the presence of a parenting plan will decrease the likelihood of a court ruling and procedural conflicts and increase the comprehensiveness of the agreements, the child's participation in the procedure, satisfaction, compliance, and the likelihood of parents updating the agreements. These changes, which are contingent on the parenting plan, are assumed to be in the child's best interest. Taking compliance with the agreement as an example, it is assumed that parents who are able to draw up a parenting plan together are also more likely to comply with the arrangements made. This in turn may enhance child well-being, because if both parents comply, they will be less likely to expose their child to different rules and norms, which is known to decrease child well-being (Harris-Short, 2010). Thus, greater compliance with the parenting plan may enhance child well-being.

The lines at the bottom of Figure 1 represent how the effect of the parenting plan on child well-being may be mediated through family outcomes. Here it is assumed that when parents draw up a parenting plan, they have more contact and engage in less conflict. Figure 1 suggests that higher levels of contact and lower levels of parental conflict are in the child's best interest. If a parenting plan lowers parental conflict, 
it may also enhance child well-being; since parental conflict is known to negatively affect child well-being (Amato, 2010), lowering conflict will be in the child's best interest. Thus, we expect that the positive effect of the parenting plan may be mediated through both procedural and family outcomes.

\section{METHOD}

\section{Data}

In this study, we analyse data from the first and second wave of the New Families in the Netherlands survey. The first wave of the survey (Poortman, Van der Lippe and Boele-Woelki, 2014), which was conducted in 2012/2013, involved formerly married parents who ended their relationship in 2008 (i.e. before the new divorce law came into effect) and formerly married parents, parents in a registered partnership, and cohabiting parents with minor children who ended their relationship in 2010 (i.e. after the new divorce law came into effect). The sample was randomly drawn by Statistics Netherlands. Both former partners were contacted by letter and invited to complete a web survey covering their legal arrangements and other characteristics before, during, and after their separation. For comparison purposes, we only selected formerly married parents in both groups. Response rates were 44 per cent for formerly married parents who divorced in 2008 and 43 per cent for those who divorced in 2010, which is quite similar. For the second wave (Poortman, Stienstra and De Bruijn, 2018), which was conducted in 2015/2016, those who ended their relationship in 2010 were approached again to participate in the survey. The second wave of data collection had a response rate of 66 per cent, which may indicate some selectivity on destabilizing issues such as higher levels of parental conflict.

For this study, we selected only formerly married parents who ended their relationship in 2008 and participated in the survey in 2012/2013 (first wave) and formerly married parents who ended their relationship in 2010 and participated in the second wave of the survey $(2015 / 2016) .{ }^{1}$ Our selection allowed us to exclude potential time effects, because the data on both groups refer to the five-year period after their divorce, meaning that both groups had a comparable time period to adjust to their post-divorce situation. Additionally, we compared only those who made written arrangements regarding their child, based on what parents themselves reported about their written arrangements.

Parents who divorced in 2008 were asked 'Were your divorce agreements about your children (e.g., where the children live, child support) recorded in writing? And in what form?' The possible answer categories are shown in Table 1. Those who divorced in 2010 were first asked whether they had drawn up a parenting plan; if not, their question was similar to the question posed to those who divorced in 2008. Respondents could choose more than one answer, and if they did so we ascribed the 'strictest' answer as their sole answer (court-issued ruling $>$ written arrangement $>$ verbal arrangement $>$ no arrangement $>$ don't know). Table 1 shows that in 2008, most divorcing parents set out their child arrangements in a divorce agreement, whereas in 2010 most did so in a parenting plan. Both groups have parents who made no arrangements, verbal arrangements, or needed a court-issued ruling. Some respondents further indicated that they had recorded their arrangements in a document that 
Table 1. Descriptive statistics for arrangements made (by divorce year)

\begin{tabular}{llrllr}
\hline \multirow{2}{*}{ Sort of arrangement } & \multicolumn{3}{c}{2008} & & \multicolumn{2}{c}{2010} \\
\cline { 2 - 3 } \cline { 6 - 6 } & $\mathrm{N}$ & $\%$ & & $\mathrm{~N}$ & $\%$ \\
\hline Parenting plan & 29 & 4.00 & & 1,604 & 91.97 \\
Divorce agreement & 597 & 82.34 & & 40 & 2.29 \\
Divorce petition & 17 & 2.34 & & 11 & 0.63 \\
Verbal arrangements & 26 & 3.59 & & 9 & 0.52 \\
No arrangements & 27 & 3.72 & & 25 & 1.43 \\
Court-issued ruling & 19 & 2.62 & & 44 & 2.52 \\
Other document & 6 & 0.83 & & 4 & 0.23 \\
Don't know & 4 & 0.55 & & 7 & 0.40 \\
Total & 725 & & 1,744 & \\
\hline
\end{tabular}

can be considered unusual, given the year in which they divorced (a parenting plan in 2008 and a divorce agreement in 2010). This may indicate that some parents were not aware of the formal name of their respective document. Note that even though those who divorced in 2010 record their arrangements in writing relatively more than those who divorced in 2008, the absolute number of arrangements other than a divorce agreement or parenting plan are small. To avoid potential error and/or bias in our results, we therefore only compare parents who documented their arrangements in a divorce agreement in 2008 and parents who documented their arrangement in a parenting plan in 2010.

After making this selection, we had a total sample of 2,201 divorced respondents who made written arrangements regarding their children. We then excluded parents who reported having children younger than four or older than seventeen $(n=250)$, because the well-being measure used in this study is best for children aged four to seventeen (for more details, see below). We further excluded 168 respondents because they had a missing value on the child well-being measure, which is a key variable in this study. Another 56 respondents were excluded because they did not know whether the court was required to intervene in their child-related arrangements $(n=37)$, or whether they had amended their agreements $(n=7)$ or asked their child's opinion while making the arrangements $(n=12)$. A total of 51 respondents were omitted from the analyses because they were missing a value for at least one of the dependent or independent variables. Regarding our control variables, 100 respondents were excluded because they reported living in a residential arrangement other than mother residence, father residence or residential co-parenting, and 83 respondents were excluded because they did not know whether or not their expartner was in a new relationship. A total of 18 respondents were omitted from the analyses because they had a missing value for at least one of the control variables. We were ultimately left with 1,055 respondents from 916 households who divorced in 2010 and 420 respondents from 328 households who finalized their divorce in 2008. Implying that respectively in about $15 \%$ and $28 \%$ of the households in our sample, both partners participated. 


\section{Measures}

Satisfaction. Respondents were asked 'Looking back, to what extent are you now satisfied with the original agreements made during the divorce?' Answer categories ranged from 'very satisfied' (1) to 'very dissatisfied' (5). We changed the direction of the variable, so that a higher score on this variable indicates a higher level of satisfaction with the agreements made.

Compliance. This variable reflects the extent to which the former partners honoured the arrangements they made for their children during their divorce. The respondents could indicate that the respondent and or his/her ex-partner; 'always honored the agreements made' (1), 'often honored the agreements made' (2), 'sometimes honored the agreements made' (3) or '(Almost) never honored the agreements made' (4). Again, we changed the direction of the variable, so that a higher score on this variable indicates a higher level of compliance with the agreements made.

Procedural conflicts. Respondents were asked: 'To what extent was there conflict between you and your ex-partner about the issues that needed to be agreed for the divorce?' The possible answer categories ranged from 'No conflict' (0) to 'A lot of conflict' (3).

Comprehensiveness of the arrangement. To assess the comprehensiveness of the arrangements made, respondents were shown 10 items and asked whether each item was included in their parenting plan, with 'yes' $=1$ and 'no' $=0$. Four of the items are mandatory under current Dutch legislation; the other six items are not mandatory but known to be common in parenting plans. Examples of these 'extra' items are: 'How to handle daily decisions about the children's care', and 'Children's contact with other family members (e.g., grandparents).' We constructed a count variable ranging from 0 to 10 , with a higher score indicating a more comprehensive post-divorce arrangement.

Child consulted. Respondents were asked: 'When making the agreements about your children, did you consult them?' We constructed three dichotomous variables from the answer categories that indicate whether: (i) the child was consulted, (ii) the child was not consulted, and (iii) the children were too young to consult, according to the respondent.

Changed agreement. This variable reflects whether parents altered the arrangements they made during the divorce at a later date. Respondents were asked: 'Later, did you and your ex-partner alter the agreements that were made about your children during the divorce?' We used the answers to construct three dichotomous variables indicating whether the respondent and his/her ex-partner altered their agreements mutually, did so with help of a third (legal) party, or did not alter their agreements.

Court decided. Respondents were asked: 'Did you and your ex-partner go to court for a court ruling? If yes, on which points did you ask the court to make a decision?' Multiple answers were possible, but because we were interested in whether or not parents required a court decision rather than in the issue itself, we decided to distinguish between whether the court needed to make a decision (1) or not (0). Note that the court's decision may refer to only a single item and that parents may have still drawn up the rest of the post-divorce arrangement themselves. This differs from the court ruling presented in Table 1, which concerns a ruling on the entire child arrangement.

Contact. Our contact measure relates to the frequency of parental contact. The respondents could indicate how often they have contact with their ex-partner, with 
answer categories ranging from 'Daily' (0) to 'Never' (8). We changed the direction of this measure so that a higher score on this variable indicates a higher level of parental contact.

Post-divorce conflict. This variable was constructed from a list of eight items accompanying the question: 'Has your ex-partner done any of the following things since the separation?' The items were: 'Blamed you for something'; 'Said bad things about you to others'; 'Called or dropped in uninvited'; 'Turned the children against you'; 'Made false accusations'; 'Discredited your shared past'; 'Shouted at you, argued aggressively'; 'Threatened you with violence', with 'yes' $=1$. We computed a count variable ranging from 0 to 8 , with a higher score indicating a higher level of parental conflict.

Post-divorce tension. This variable captured the current level of tension between the divorced parents. Respondents were presented the following question 'How often are there currently tensions or conflicts between you and your ex-partner?' The response categories ranged from 'almost never' (1) to 'very often' (4).

Child well-being. To construct this measure, we asked respondents to report on only one of their children. In order to select the child on which parents report, parents with more than one child were asked to report on their youngest child if they had children older than 10 years. When all their children were younger than the age of 10, parents were asked to report on their eldest. We used the parent report version of the Strengths and Difficulties Questionnaire (SDQ) (Goodman, 1997) to construct this measure. Following the instructions on the SDQ website, and excluded the prosocial behaviour subscale. We thus computed the SDQ Total Difficulties Score by adding up the emotional symptoms, conduct problems, hyperactivity and peer problems subscales. These subscales have 5 questions each, and parents can response on each item with not true (0), somewhat true (1), and certainly true (2). This variable can range between 0 and 40, with a higher score on the SDQ representing more child difficulties and thus lower child well-being (Goodman, 1997). Because the distribution of this variable was rightly skewed, we log-transformed our dependent variable using the natural logarithm.

Controls. In all our analyses, we control for the child's residence arrangement and differentiated between residence with mother, residence with father, or residential co-parenting. As explained earlier, it might be that the change in the law (or changes in norms over time) have led to differences in residence arrangements between the two groups under study. We also controlled for the gender and the age of the child who is the subject of the SDQ, the highest level of education of the child's parents, ranging from 'Did not complete elementary school' (1) to 'Post-graduate' (10). Other control variables included in the analyses are whether the child and/or one of its parents encountered any problems prior to the divorce (e.g. psychiatric illness, psychological problems), whether the child's father or mother has a new partner, the level of pre-divorce conflict, and the gender of the responding parent. With the exception of the child's residence arrangements, there are no reasons to expect any differences between the two groups under study regarding these control variables; nonetheless, we decided to control for them in order to detect possible selectivity in the sample. Descriptive statistics for all variables under study can be found in Table 2. 
Table 2. Descriptive statistics for variables under study (by divorce year)

\begin{tabular}{|c|c|c|c|c|c|c|}
\hline \multirow[b]{2}{*}{ Variables } & \multicolumn{3}{|c|}{$2008(n=420)$} & \multicolumn{3}{|c|}{$2010(n=1,055)$} \\
\hline & Range & Mean & $\mathrm{SD}^{\mathrm{a}}$ & Range & Mean & $\mathrm{SD}^{\mathrm{a}}$ \\
\hline \multicolumn{7}{|l|}{ Procedural outcomes: } \\
\hline Satisfaction & $0-4$ & 2.600 & 1.065 & $0-4$ & 2.690 & 1.054 \\
\hline Compliance & $0-3$ & 2.267 & 0.852 & $0-3$ & 2.323 & 0.878 \\
\hline Procedural conflicts & $0-3$ & 1.005 & 0.911 & $0-3$ & 1.006 & 0.944 \\
\hline $\begin{array}{l}\text { Comprehensiveness of the } \\
\text { agreement }\end{array}$ & $0-10$ & 5.619 & 2.453 & $0-10$ & 7.968 & 2.157 \\
\hline Child consulted (Yes) & $0 / 1$ & 0.236 & - & $0 / 1$ & 0.274 & - \\
\hline Child consulted (No) & $0 / 1$ & 0.321 & - & $0 / 1$ & 0.305 & - \\
\hline Child consulted (NA: age) & $0 / 1$ & 0.443 & - & $0 / 1$ & 0.421 & - \\
\hline Changed agreement (Yes) & $0 / 1$ & 0.305 & - & $0 / 1$ & 0.434 & - \\
\hline $\begin{array}{l}\text { Changed agreement (Yes, with } \\
\text { third party) }\end{array}$ & $0 / 1$ & 0.117 & - & $0 / 1$ & 0.130 & - \\
\hline Changed agreement (No) & $0 / 1$ & 0.579 & - & $0 / 1$ & 0.436 & - \\
\hline Court decided & $0 / 1$ & 0.119 & - & $0 / 1$ & 0.118 & - \\
\hline \multicolumn{7}{|l|}{ Family outcomes: } \\
\hline Contact & $0-8$ & 5.331 & 1.714 & $0-8$ & 5.554 & 1.857 \\
\hline Post-divorce conflict & $0-8$ & 2.786 & 2.550 & $0-8$ & 1.648 & 2.240 \\
\hline Post-divorce tension & $0-3$ & 0.583 & 0.803 & $0-3$ & 0.709 & 0.875 \\
\hline \multicolumn{7}{|l|}{ Child outcome: } \\
\hline SDQ $(\log )$ & $0-2.890$ & 1.396 & 0.765 & $0-3.045$ & 1.313 & 0.805 \\
\hline \multicolumn{7}{|l|}{ Controls: } \\
\hline Female & $0 / 1$ & 0.576 & - & $0 / 1$ & 0.609 & - \\
\hline Highest education in thehousehold & $1-10$ & 7.176 & 1.700 & $2-10$ & 7.382 & 1.537 \\
\hline Pre-divorce conflict & $0-3$ & 1.255 & 0.818 & $0-3$ & 1.212 & 0.770 \\
\hline Parental problems & $0-3$ & 0.400 & 0.646 & $0-3$ & 0.385 & 0.652 \\
\hline Gender of focal child (girl) & $0 / 1$ & 0.450 & - & $0 / 1$ & 0.493 & - \\
\hline Age of focal child & $5-17$ & 12.914 & 2.720 & $6-17$ & 13.209 & 2.680 \\
\hline Child problems & $0-3$ & 0.505 & 0.833 & $0-3$ & 0.483 & 0.817 \\
\hline Respondent has new partner & $0 / 1$ & 0.690 & - & $0 / 1$ & 0.643 & - \\
\hline $\begin{array}{l}\text { Ex-partner of respondenthas } \\
\text { new partner }\end{array}$ & $0 / 1$ & 0.710 & - & $0 / 1$ & 0.742 & - \\
\hline Residential co-parenting & $0 / 1$ & 0.245 & - & $0 / 1$ & 0.373 & - \\
\hline Mother residence & $0 / 1$ & 0.693 & - & $0 / 1$ & 0.572 & - \\
\hline Father residence & $0 / 1$ & 0.062 & - & $0 / 1$ & 0.055 & - \\
\hline
\end{tabular}

${ }^{\mathrm{a}}$ Not presented for dichotomous variables

\section{Analytical Strategy}

Our analyses allow for the structure of the data because in some cases, both former partners participated in the survey. To make this allowance, we clustered the regression analyses at the household level. We examined the effectiveness of the parenting 
plan in two stages. First, we reported clustered linear, multinomial and logistic regressions to see whether the introduction of the parenting plan has affected procedural outcomes and family outcomes. Second, we examined the effect of introducing the parenting plan (and its assumed outcomes) on child well-being, once again using clustered linear regressions. In both analyses, we estimated four models. The first model examines the effect of the parenting plan solely on the basis of the control variables. Although some of the control variables may be more specific to family outcomes and others to procedural outcomes or child outcomes, we decided to control for all control variables in all analyses for reasons of consistency and completeness. In the second model, we added the measures that relate to procedural outcomes to the analyses. In the third model, we added measures that relate to family outcomes and our control variables. In our final model (Model 4), we included all the variables mentioned; these are the control variables and the variables that reflect on procedural and on family outcomes. We performed additional robustness checks (not shown here), estimating our models by means of multilevel analyses and propensity score matching; these results showed the same pattern as the results presented in this study.

\section{RESULTS}

Table 3 shows the results of the effect of the parenting plan on procedural outcomes. Here we present linear, multi-nominal and logistic regressions where we only report the effect of the parenting plan on the given outcome. Table 3 indicates that the introduction of the parenting plan has led to parents making more comprehensive agreements regarding their children; this effect is significant throughout the four models. A similar effect is found for the likelihood that parents alter their arrangements later. Throughout the four models, we see that parents with parenting plans are more likely to change their agreements themselves, compared with those who made written arrangements before the 2009 divorce law. Moreover, with the exception of Model 2 (Table 3), the introduction of the parenting plan is found to have led to more parents amending their agreements with the help of a third (legal) party. Conversely, the parenting plan was not found to affect satisfaction and compliance with the agreements made. When we also control for family outcomes, we see that procedural conflicts and the likelihood that the parents needed a court ruling increased after the mandatory parenting plan was introduced, but this finding loses its significance when we add all the other procedural effects. For the other procedural outcomes, we find that the introduction of the parenting plan seems to have had no effect on whether parents consulted their child about the arrangements.

Table 4 shows that the introduction of the parenting plan also affected certain family outcomes. Our results show that parents with a parenting plan encounter lower levels of severe post-divorce conflict, but higher levels of post-divorce tension. These effects are found across all four models. The parenting plan was not found to affect the level of contact between parents.

Tables 3 and 4 reveal that the introduction of the parenting plan made little or no difference to the procedural and family outcomes. In Table 5, we examine whether 


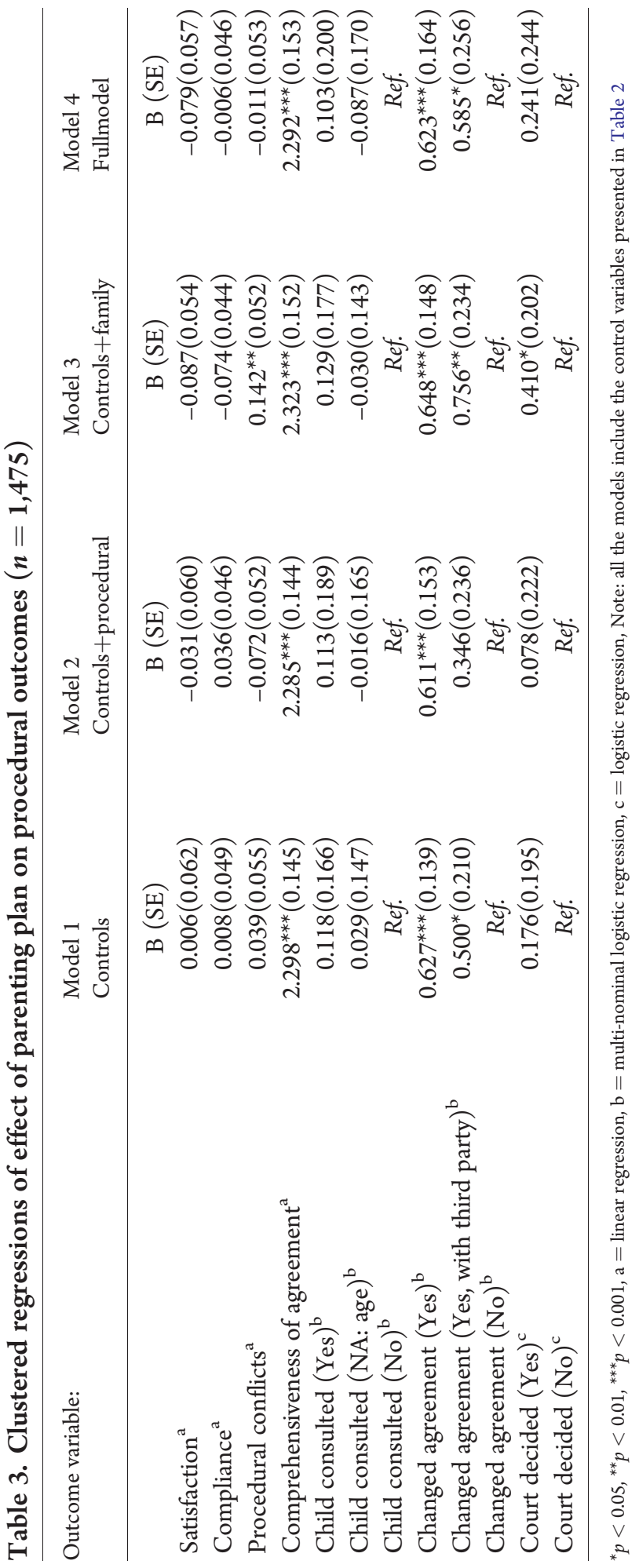


Table 4. Clustered linear regressions of effect of parenting plan on family outcomes $(n=1,475)$

\begin{tabular}{lcccc}
\hline Outcome variable: & $\begin{array}{l}\text { Model 1 } \\
\text { Controls }\end{array}$ & $\begin{array}{l}\text { Model 2 } \\
\text { Controls+procedural }\end{array}$ & $\begin{array}{l}\text { Model 3 } \\
\text { Controls+family }\end{array}$ & $\begin{array}{l}\text { Model 4 } \\
\text { Full model }\end{array}$ \\
\hline Family outcomes: & $\mathrm{B}(\mathrm{SE})$ & $\mathrm{B}(\mathrm{SE})$ & $\mathrm{B}(\mathrm{SE})$ & $\mathrm{B}(\mathrm{SE})$ \\
$\begin{array}{l}\text { Contact } \\
\text { Post-divorce } \\
\text { conflict }\end{array}$ & $-0.108(0.102)$ & $-0.039(0.102)$ & $-0.009(0.103)$ & $-0.006(0.106)$ \\
$\begin{array}{c}\text { Post-divorce } \\
\text { tension }\end{array}$ & $0.160^{* *}(0.142)$ & $-1.063^{* * *}(0.130)$ & $-1.172^{* * *}(0.127)$ & $-1.120^{* * *}(0.125)$ \\
\hline
\end{tabular}

${ }^{*} p<0.05,{ }^{* *} p<0.01,{ }^{* * *} p<0.001$, Note: all the models include the control variables presented in Table 2

Table 5. Clustered linear regression of effects on child difficulties (log) $(n=1,475)$

\begin{tabular}{lcccc}
\hline Variable & $\begin{array}{l}\text { Model 1 } \\
\text { Controls }\end{array}$ & $\begin{array}{l}\text { Model 2 } \\
\text { Controls+procedural }\end{array}$ & $\begin{array}{l}\text { Model 3 } \\
\text { Controls+family }\end{array}$ & $\begin{array}{l}\text { Model 4 } \\
\text { Full model }\end{array}$ \\
\hline & B (SE) & B (SE) & B (SE) & B (SE) \\
Parenting plan & $-0.030(0.046)$ & $-0.003(0.051)$ & $-0.023(0.047)$ & $-0.004(0.052)$ \\
Procedural outcomes: & & & & $-0.020(0.024)$ \\
\hline Satisfaction & & $-0.047^{*}(0.023)$ & & $-0.038(0.029)$ \\
Compliance & $-0.063^{*}(0.028)$ & & $0.005(0.027)$ \\
Procedural conflicts & $0.014(0.027)$ & & $-0.013(0.009)$ \\
Comprehensiveness & $-0.013(0.009)$ & & $-0.046(0.054)$ \\
$\quad$ of agreement & & & $-0.039(0.047)$ \\
Child consulted (Yes) & $-0.058(0.054)$ & & Ref. \\
Child consulted (NA: age) & $-0.047(0.050)$ & & $0.041(0.044)$ \\
Child consulted (No) & Ref. & & $-0.010(0.068)$ \\
Changed agreement (Yes) & $0.035(0.044)$ & & Ref. \\
Changed agreement (Yes, & $0.038(0.067)$ & & $-0.114(0.072)$ \\
$\quad$ with third party) & & & Ref. \\
Changed agreement (No) & Ref. & & \\
Court decided (Yes) & $-0.106(0.072)$ & & $-0.015(0.014)$ \\
Court decided (No) & Ref. & & $0.016(0.012)$ \\
Family outcomes: & & $-0.018(0.013)$ \\
Contact & & $0.019(0.011)$ & \\
Post-divorce conflict & & & & \\
Post-divorce tension & & & & \\
\hline
\end{tabular}

${ }^{*} p<0.05,{ }^{* *} p<0.01,{ }^{* * *} p<0.001$, Note: all the models include the control variables presented in Table 2

the introduction of the parenting plan affected child well-being and whether any such effect is mediated through procedural and/or family outcomes. In all of the models associated with Table 5, we find that the introduction of the parenting plan does not seem to have affected child well-being. 
Although these results show that the introduction of the parenting plan had no direct overall effect on child well-being, Models 2, 3 and 4 examine whether the procedural and family outcomes of the parenting plan may have done so. Among the outcomes affected by the parenting plan, only post-divorce tension seems to affect child well-being negatively. However, when we exclude post-divorce tension from the analyses, post-divorce conflict becomes significant (analyses not shown here), which of course can be attributed to their high level of correlation $(r=0.537$, analyses not shown). Only Model 2 (Table 5) shows that satisfaction and compliance with the agreements diminish child difficulties, but these effects vanish when we control for family outcomes as well. Furthermore, the level of parental contact, postdivorce conflict, procedural conflicts, comprehensiveness of the agreements, whether the child was consulted, whether the agreements were altered and whether the court made a decision regarding the agreements do not seem to affect child well-being.

\section{DISCUSSION}

This study aimed to provide new insights into the effectiveness of the parenting plan in the Netherlands. On the introduction of the mandatory parenting plan in 2009, the assumption was that it would improve the relationship between partners after divorce and reduce problems in divorce proceedings. It was believed that the plan itself and its assumed effects on these family and procedural outcomes were in the child's best interest.

In this study, which takes the form of a natural experiment, we reveal that the introduction of the mandatory parenting plan led to few differences either in procedural or in family outcomes. With respect to procedural outcomes, our conclusion is that the level of compliance, satisfaction, child's participation, court rulings and procedural conflicts were not affected by the change in the law. Nonetheless, some procedural outcomes did change after the 2009 reform. In line with previous research by Tomassen-van der Lans (2015), we see that parents make relatively more agreements regarding their children than before the change in the law. This finding is twofold: a growing number of parents made written arrangements after 2009, and the arrangements themselves were more comprehensive.

Our study also revealed that those who divorced after 2009 alter their agreements more often than those who divorced prior to the change in the law. This may be because the Dutch government advises parents to update their parenting plan regularly so that it reflects the child's needs. An alternative explanation might be that after the introduction of the parenting plan, post-divorce agreements regarding children became more comprehensive and there was therefore a greater need to update the agreements. In sum, the introduction of the Promotion of Continued Parenting and Proper Divorce Act in 2009 encouraged more parents to document their child arrangements in writing, make these arrangements more comprehensive, and update these arrangements more often.

Besides examining procedural outcomes affected by the 2009 divorce law, this study also examined its effect on family outcomes. There is no empirical evidence that the level of parental contact altered after the 2009 divorce law. Our findings concerning parental conflict are mixed: although the level of post-divorce tension 
increased after 2009, we also see a decrease in extreme occurrences of parental conflict. On the one hand, this suggests that the guidance offered by a parenting plan helps parents overcome extreme levels of conflict and therefore communicate with less hostility; on the other hand, these parents divorced for a reason, but instead of expressing their displeasures with each other explicitly, they keep it to themselves and thus experience more tension. The increase in residential co-parenting arrangements means that more parents are dealing with each other directly, which might explain the rise in levels of post-divorce tension between parents since the introduction of the parenting plan. An alternative explanation may lie in the selectivity of the data; the sample-parents who divorced after 2009 and whose data are present in both the first and the second wave-entails a willingness to participate in the survey, which could be a proxy for parents who encounter lower levels of severe conflict.

The Dutch government assumed that the new legislation would not only reduce procedural and family problems but would also be in the child's best interest. Contrary to expectations, this study provides empirical evidence that the presence of a parenting plan does not seem to affect child well-being. This finding pertains to both the direct effect of the new legislation and to the mediated effect through procedural and family outcomes. There is only one exception: post-divorce tension seems to have increased after the introduction of the 2009 divorce law, and higher post-divorce tension is related to more child difficulties. This might suggest that the new divorce law had a slightly negative effect. However, we know that post-divorce parental conflict is a key stressor for children (Musick and Meier, 2010). If we exclude the level of post-divorce tension from the model, we find the same negative effect for post-divorce conflict, indicating that the new divorce law had a slightly positive effect because those who divorced after 2009 encountered lower levels of post-divorce conflict. Nonetheless, the main effect of the parenting plan remained unrelated and unchanged with child well-being when post-divorce tension and/or post-divorce conflict is added to the model. Therefore, we must be cautious about drawing conclusions in this respect and recommend that future research aim to untangle this relationship.

Overall, we found that the introduction of the 2009 divorce law led to few changes either in the divorce proceedings or in post-divorce family life. We found no empirical support for the Dutch government's belief that the new legislation would be in the child's best interest. We can attribute much of these findings to the fact that, prior to the 2009 divorce law, parents already made (written) arrangements regarding their children. Making such written agreements mandatory may have not been such a dramatic change to begin with and would therefore not have had a major effect. Alternatively, although we examine and control for satisfaction and compliance with the agreements, we do not know whether parents actually meant them to assist them in the post-divorce period or whether they saw them as a mere formality to finalize their divorce. If the latter, this may explain why parenting plans were found to have so little effect: parents did not actually use their arrangements to guide them in the post-divorce situation. In line with previous research (Amato and Sobolewski, 2001), this study also reveals the impact of parental conflict on child well-being. Policymakers should therefore investigate how they can help parents resolve their conflicts, or at least protect their child against the effects of that conflict. 
The introduction of the mandatory parenting plan was a noble attempt in this direction, but it may have been too ambitious to expect it to lead to greater child wellbeing, especially when parents are obliged to come to an agreement just when they are ending their relationship.

Even though our study improves on previous research and informs the public debate regarding parenting plans, we must note some limitations. The first relates to our sample. Those who divorced in 2010 participated in both the first and the second wave of the survey, and may constitute a selective group with respect to the level of parental conflict. As a result, we may underestimate the effects of parental conflict or the effect of the parenting plan on parental conflict. The second limitation concerns the selected time period. We examined the effects of parental arrangements five years after divorce, but it may be that the effect of the new law will arise somewhat later, or that, regardless of the divorce proceedings, parents face similar problems in the first five years after divorce. Because we know that divorce also has long-term implications in the life course (Ahrons, 2007), the new legislation may not diminish the negative consequences immediately but will do so later on in life. Future research should therefore examine the effects of the 2009 divorce law over a longer time period.

All in all, our study provides new information for the debate regarding Dutch parenting plans and suggests that the mandatory parenting plan is not as successful as Dutch lawmakers intended it to be. On the other hand, our study also shows that the mandatory parenting plan had not had the negative effects forecast by critics.

\section{FUNDING}

This research was supported by Research Talent Grant 406-13-090, awarded by the Netherlands Organization for Scientific Research (NWO).

The NFN data were collected by Utrecht University in collaboration with Statistics Netherlands (CBS). Funding was awarded under grant 480-10-015 from the Medium Investments Fund of the Netherlands Organization for Scientific Research (NWO) and by Utrecht University.

\section{NOTE}

1. For each sample the respondents were selected on the divorce year of 2008 and 2010, respectively, still a small number of respondents finalized their divorce in a different year. As a result we only selected those who divorced in the year 2000 till 2008 to represent the 2008-group and omitted those who divorced after 2008 (because they do not fit the sample selection). The same argumentation holds for the 2010-group, this group is represented by divorces from March 2009 till 2012. These selections are made to assure that the difference in legislation can be tested.

\section{REFERENCES}

Ahrons, C. R. (2007) 'Family ties after divorce: Long-term implications for children', Family Process 46(1), 53-65.

Amato, P. R. (2010) 'Research on divorce: Continuing trends and new developments', Journalof Marriage and Family 72(3), 650-66.

Amato, P. R. and Sobolewski, J. M. (2001) 'The effects of divorce and marital discord on adult children's psychological well-being', American Sociological Review 66(6), 900-21. 
Antokolskaia, M. V. (2010) 'Pleidooi voor evaluatie van de flitsscheiding', in M. V. Antokolskaia and L. M. Coenraad (eds), Het nieuwe scheidingsrecht. Ouderschapsplan, positie van het kind, regierechter en collaborative divorce, Den Haag: Boom Juridische uitgevers, 51-66.

Bunthof, A. (2006) 'Ouderschap en scheiding' Maatwerk 7(4), 179-80.

Coenraad, L. M. and Antokolskaia, M. V. (2010) 'Inleiding: nieuw scheidingsrecht en meer nieuws op stapel', in M. V. Antokolskaia and L. M. Coenraad (eds), Het nieuwe scheidingsrecht. Ouderschapsplan, positie van het kind, regierechter en collaborative divorce, Den Haag: Boom Juridische uitgevers, 9-16.

Goodman, R. (1997) 'The strengths and difficulties questionnaire: a research note', Journal of Child Psychology and Psychiatry 38(5), 581-86.

Harris-Short, S. (2010) 'Resisting the march towards 50/50 shared residence: rights, welfare and equality in post-separation families', Journal of Social Welfare \& Family Law 32(3), 257-74.

Lamb, M. E., Sternberg, K. J. and Thompson, R. A. (1997) 'The effects of divorce and custody arrangements on children's behavior, development, and adjustment', Family Court Review 35(4), 393-404.

Loeb, E. (2009) 'Het ouderschapsplan', in K. Boele-Woelki (ed.), Actuele ontwikkelingen in het familierecht, Nijmegen: Ars Aequi Libri, 17-26.

Meyer, B. D. (1995) 'Natural and quasi-experiments in economics', Journal of business \&' Economic Statistics 13(2), 151-61.

Ministerie van Jeugd en Gezin (2008) De Kracht van het Gezin: Nota Gezinsbeleid 2008. Den Haag, retrieved from http://www.jeugdengezin.nl

Ministerie van Veiligheid en Justitie (2012) Als ouders uit elkaar gaan. Utrecht, retrieved from http://www.kinderbescherming.nl

Musick, K. and Meier, A. (2010) 'Are both parents always better than one? Parental conflict and young adult well-being', Social Science Research 39(5), 814-30.

Poortman, A. and Gaalen, R. van. (2017) 'Shared residence after separation: a review and new findings from the Netherlands', Family Court Review 55(4), 531-44.

Poortman, A., Lippe, T. van der and Boele-Woelki, K. (2014) Codebook of the Survey New Families in the Netherlands (NFN). First wave. Utrecht, the Netherlands: Utrecht University.

Poortman, A., Stienstra, K. and Bruijn, S. de. (2018) Codebook of the Survey New Families in the Netherlands (NFN). Second wave. Utrecht, the Netherlands: Utrecht University.

Rijksoverheid (2009) Uit elkaar. . .En de kinderen dan? Ministerie van Jeugd en Gezin, 1-26.

Rijksoverheid (2013). Wanneer moet ik een ouderschapsplan opstellen?. Retrieved from http://www. rijksoverheid.nl/onderwerpen/scheiden/vraag-en-antwoord/ouderschapsplan.html

Schepard, A. (2001) 'An introduction to the model standards of practice for family and divorce mediation' Family Law Quarterly 35(1), 1-25.

Schonewille, F. (2009) 'De Wet bevordering voortgezet ouderschap en zorgvuldige scheiding is een feit: exit klassieke omgangsregeling', Weekblad voor Privaatrecht, Notariaat en Registratie, 6800, $1-22$.

Smits, V. M. (2015) Participatie van het kind bij het ouderschapsplan (dissertation). Apeldoorn/Antwerpen: Maklu-Uitgevers, 1-378.

Spruijt, E. and Kormos, H. (2014) Handboek scheiden en de kinderen: voor de beroepskracht die met scheidingskinderen te maken heeft Houten: Bohn Stafleu van Loghum.

Staatsblad (2008), 500. Wetbevordering voortgezet ouderschap en zorgvuldige scheiding, Den Haag: SDU uitgevers.

Ter Voert, M. J. and Geurts, T. (2013) Evaluatie ouderschapsplan: Een eerste verkenning. Den Haag: WODC.

Tomassen-van der Lans, M. (2015) Het verplichte ouderschapsplan: regeling en werking (dissertation), Den Haag: Boom Juridische uitgevers, 1-359.

Westphal, S. K. (2015) Are the kids alright? Essays on postdivorce residence arrangements and children's well-being (dissertation), Utrecht, the Netherlands: Utrecht University. 